\title{
Teacher Supply and Demand: The School Level Perspective
}

\author{
Smadar Donitsa-Schmidt ${ }^{*}$, Ruth Zuzovsky \\ Kibbutzim College of Education, Technology and the Arts, Tel-Aviv, Israel \\ *Corresponding author: smadar@macam.ac.il
}

Received April 30, 2014; Revised June 06, 2014; Accepted June 12, 2014

\begin{abstract}
This study seeks to investigate the teacher shortage from the school perspective. It was guided by the assumption that activities occurring on the micro level, i.e., strategies implemented by school principals in order to cope with the shortage, mask the situation. Following this assumption the study aimed to reveal these strategies and their impact on teaching and learning in schools. The research methodology included surveys of school principals and regional inspectors and examination over two years of job advertisements appearing on teacher union internet sites. Findings reveal an ongoing search for teachers throughout the school year and a balance between supply and demand toward the beginning of the school year. The most common strategies used by principals to cope with the demand are increasing teaching loads of existing teachers, hiring under-qualified and uncertified teachers, and employing temporary teachers for long periods of time. These findings redirect the problem of a quantitative teacher shortage toward the problem of a hidden shortage that relates to the quality of the teaching force.
\end{abstract}

Keywords: teacher shortage, supply and demand, school level perspective

Cite This Article: Smadar Donitsa-Schmidt, and Ruth Zuzovsky, "Teacher Supply and Demand: The School Level Perspective." American Journal of Educational Research, vol. 2, no. 6 (2014): 420-429. doi: 10.12691/education-2-6-14.

\section{Introduction}

A shortage of teachers is common in many western countries, among them the UK, Australia, and the US. A number of international reports including those of the OECD [1,2], the Eurydice Network[3], and reports based on the US National Center of Educational Statistics [4] indicate difficulties in staffing teaching positions. These difficulties do not stem only from increased enrollment and retirement of teachers but also from a high turnover of teachers who move from one school to another or leave the occupation altogether. This latter phenomenon suggests the image of a 'revolving door', where a large number of teachers are in transition - into, between, or out of schools [4,5]. This large turnover causes not only staffing problems but consequently also threatens the quality of teachers and the pupils' performances.

\subsection{Defining Teacher Shortage}

According to labor supply and demand theory [6], demand is defined as the number of available job positions offered for certain compensation. Supply is defined as the number of qualified individuals both able and willing to offer their services in a particular line of work, depending on compensation. Compensation includes wages, bonuses, future earning possibilities and other types of rewards that can be encompassed under the heading of 'working conditions' and incentives, including status in society.

Teacher shortage in the labor market occurs, therefore, when demand exceeds supply and is the result of an increase in demand, a decrease in supply or both occurring simultaneously [7]. However, the operational definition of teacher shortages is not consistent. Some define it according to an observable quantitative measure, i.e., the number of unfilled teaching positions. Since it is hard to rely on this measure as usually most positions are filled at the beginning of the school year and no class is left without a teacher, another measure is a 'hidden shortage', i.e. the number of under-qualified teachers hired to fill the empty positions [[1], p.22]. These include both unqualified teachers as well as teachers who were trained to teach other school subjects or class levels (out-of-field).

\subsection{Factors Effecting Teacher Shortage}

Identifying the factors that affect a teacher shortage depends on adopting one of two viewpoints: one that perceives this problem as stemming from factors operating on the macro system level, i.e. nation, district; and the other that attributes it to factors operating on the micro level, i.e., the school.

Macro factors that affect the demand for teachers include, for example, natural student population growth, increased immigration, changes in educational policy and labor agreements. Macro factors which effect supply of teachers include, for example, status and prestige of the profession, merit-based incentives, shortened certification programs and the number of new graduates entering the profession or switching from other occupations.

Micro factors that operate on the organizational level are those that affect certain neighborhoods or certain 
schools, i.e., a decrease in students due to the greying of the population in a specific neighborhood, a decrease in the prestige of a certain school, teacher burnout due to acute discipline problems in a given school, lack of support from the principal, and problems in class management, lack of teacher autonomy, absence of professional development activities, and scarce benefits given in a certain school $[8,9]$. Although these factors do not affect the overall national balance between supply and demand, from the school perspective, these are factors responsible for the imbalance.

While national predictions tend to rely on macro factors, some researchers consider micro factors to be the most important ones and claim that a teacher shortage comes into play mostly on the school level rather than on the national level where the ratio of supply and demand remains stable over the years $[4,5,10]$. These researchers recommend to focus on the institutions themselves and 'to put the organization back' into the analysis [11].

\subsection{Ways of Coping with Teacher Shortage}

Coping with a shortage of teachers depends, to a large extent, on the way the shortage is perceived. Viewing shortage as stemming from factors operating on the macro level leads to systemic actions aimed at increasing supply such as national policies to attract talented candidates into the profession, offering alternative routes toward certification, recruiting overseas teachers, offering monetary incentives, improving working conditions and raising the image and status of teaching. All these are intended to attract and retain teachers in the profession.

Viewing the shortage as stemming from micro level factors leads school principals to act within the boundaries of their own organization in order to recruit and retrain effective teachers. These are, usually, ad hoc solutions to school needs [5], among them using substitute teachers, increasing teaching loads, hiring teachers without required qualifications and certification, employing teachers in partial positions, enlarging the number of students per class and actuating non-official cancellation of school subjects [12]. These strategies, which help principals solve the immediate quantitative shortage of teachers, create, at the same time, a hidden shortage and affect the quality of the recruited teaching workforce [13].

Viewing problems of shortage from an integrated perspective was suggested by King Rice et al. [8] who provide a policy making framework that operates on three levels: the state, the district and the school level. This framework deals with four common problems on each level: the supply of qualified teachers, recruitment of teachers to districts and schools where they are most needed, distributing teachers in an efficient and equitable way, and retaining teachers in schools. For each of these problems, they identified five broad and sometimes overlapping policy solutions: (1) offering economic incentives, (2) easing avenues into the profession, (3) improving hiring strategies, (4) providing opportunities for professional development, (5) improving working conditions. These policy strategies may be expressed differently on the three levels mentioned above (state, district and state) via different mechanisms. For instance, on the state level, hiring mechanisms may include lowering the entry admission standards, while on the school level, it could be utilizing more flexible standards of admission.

\subsection{Is There a Shortage of Teachers in Israel?}

Evidence regarding the shortage of teachers in Israel is not conclusive and depends on the indicator used. One of these indicators is the greying of the teaching force which can be predicted according to the percent of teachers aged 50 or above [1]. Data from reports by the Central Bureau of Statistics (CBS) in the past decade reveal the greying phenomena in many school subjects and on all school levels, especially in the Jewish sector $[14,15,16]$.

Two other indicators of the teacher shortage are teacher attrition, i.e., the number of new teachers leaving the profession, and the lack of motivation among young adults to enter the teaching profession. Attrition was detected in a high proportion of teachers found to be leaving the profession after five years (about half of the beginning teachers), and an increase in the percentage of teachers who permanently leave the profession each year (about $6 \%$ ) [17]. At the same time, since the teaching profession is perceived as having low status and offering low salaries and benefits [18], there is a decrease in the number of students studying to become teachers in teacher colleges. Their proportion, out of the total number of graduate students, decreased from $21 \%$ in $1995-96$ to $18 \%$ in 1999 2000 [19] and in 2009-2010 it was only 14\% [20].

These indicators and others, such as student population growth and teacher retirement, were used by the CBS to develop a model for projecting the shortage of teachers in the system. According to this model, it was predicted that in the year 2013 there will be a shortage of about 10,000 teachers [21].

These projections were rejected by the officials in the Ministry of Education, who claimed that there is a shortage only in three school subjects: English, sciences and mathematics, and that the difficulty in finding teachers occurs only in peripheral areas. They indicated that there was a teacher surplus in certain school subjects and some geographical areas based on difficulties in staffing new graduates, many of whom were graduates of shortened alternative certification programs. They also based their claims on the fact that at the beginning of every school year, no teaching positions are left vacant.

The mismatch between formal predictions regarding the teacher shortage and the Ministry's claims was the trigger for the present study. We assume that this contradiction is due to activities occurring on the micro level initiated by school principals in order to cope with the acute problems of teacher shortage they face every year. In light of these assumptions, the present study aims to learn about the issue of teacher shortage from the perspective of schools and districts. Four research questions were asked:

1. What are the reasons for the demand for teachers on the school level according to principals and regional inspectors?

2. How does teacher supply and demand change throughout the year (a) in general and (b) in specific school subjects?

3. What are the strategies used by principals to cope with the teacher shortage according to principals and regional inspectors? 
4. What is the effect of the shortage of teachers on teaching and learning in schools according to principals?

\section{Materials and Methods}

The research entailed three components: a survey of school principals, a survey of regional inspectors, and an analysis of job advertisements appearing on teacher union internet sites. Following is a description of each of these components including the research instrument used, research population and data collection procedures.

\subsection{School Principal Survey}

Data was collected through a non-anonymous online questionnaire sent to a representative sample of schools. The sampling framework included all official schools in the Israeli system (Hebrew- and Arabic-speaking) and excluded ultra-orthodox and special education schools. The sampling framework included a total of 2,783 schools. Sampling design followed the rules of a sequential random sampling procedure. Explicit strata took into consideration the three inspectorate bodies (Jewish-secular, Jewish-religious and Arab); the level of schooling (elementary, secondary) and the geographic regions of the school (seven regions). Implicit stratification was performed according to school size. The expected maximal sampling error was 3\%. The sample included 551 schools.

A total of 72 principles responded to the questionnaire (13\% response rate). Despite this low response rate, the schools whose principles responded adequately represented the distribution of schools within the total population. Following is the distribution of the schools according to inspectorate body and level of education: 34 Jewish-secular schools (47\%, 22 elementary, 12 secondary), 18 Jewish-religious schools (25\%, 11 elementary, 7 secondary), 20 Arab schools (28\%, 12 elementary, 8 secondary).

A survey questionnaire administered in May-June 2011 was field tested at an early pilot stage. The final version of the questionnaire contained three parts:

1. Questions that provided background information on the schools (e.g. number of students and teachers).

2. Likert-type questions on a five-point scale asking principals to rate the reasons underlying the need to recruit new teaches; the extent to which they implement different strategies in order to cope with the teacher shortage (e.g. increase the number of students per class, increase the workloads of teachers, hire under-qualified personnel, employ temporary or substitute teachers for long periods of time).

3. An open question asking principals to describe the effect of the teacher shortage on their school.

\subsection{Regional Inspector Survey}

This survey was based on a questionnaire administered to all inspectors in the seven geographic regions. A total of 73 inspectors, serving in different roles, responded, representing all seven regions. The questionnaire contained two parts:

1. Background information on the inspectors (e.g. gender, experience in teaching, year of experience as an inspector, role, geographic region)
2. Likert-type questions on a five-point scale asking the inspectors to rate the reasons for recruiting new teachers in their region and the extent to which they perceive school principals as implementing a set of strategies in order to cope with the teacher shortage.

\subsection{An Analysis of Advertisements on Teachers' Union Internet Sites}

Examination of job advertisements that appear regularly on the teachers' union internet sites was another source of information for analyzing teacher supply and demand throughout the year on different school levels and regarding different school subjects. These ads included both want ads placed by schools and job search ads by individuals seeking a teaching position.

The examination was carried out over a period of 24 months (February 2010-January 2013). This enabled us to identify recurring patterns of supply and demand during certain months. The sites were analyzed once every month on a fixed date since ads are automatically removed after 30 days unless they were placed again, a sign that the position was not yet filled or that the person was still seeking a teaching position. The ads were classified and counted by school level and school subject.

\section{Results}

Findings of the study will be presented according to the four research questions.

\subsection{Reasons for the Demand for Teachers on the School Level According to Principals and Regional Inspectors}

Table 1 presents percentages of principals and regional inspectors reporting on the 'most frequent' and 'very frequent' reasons for the need to hire teachers in schools and $\chi^{2}$ for significance in their measures.

Table 1. Frequent and Very Frequent Reasons for the Need to Hire Teachers in Schools According to School Principals and Inspectors

\begin{tabular}{cccc}
\hline Reasons & Principals & Inspectors & $\chi^{2}(\boldsymbol{p})$ \\
\hline Demographic growth & $39 \%$ & $59 \%$ & $5.34^{*}$ \\
Teachers' temporary leaves & $\% 29$ & $69 \%$ & $24.1^{* * *}$ \\
Teachers leaving the profession & $\% 12$ & $26 \%$ & $3.35^{*}$ \\
$\begin{array}{c}\text { Policy changes (teacher load, } \\
\text { class size, etc.) }\end{array}$ & $\% 12$ & $24 \%$ & $3.04^{*}$ \\
$\begin{array}{c}\text { Introduction of new curricula } \\
\text { * } \mathrm{p}<.05 * * * \mathrm{p}<.001\end{array}$ & $\% 12$ & $10 \%$ & 0.15 \\
\hline
\end{tabular}

The two main reasons for the high demand for teachers are the increase in the number of students in schools due to natural demographic growth and temporary leaves of teachers due to pregnancy, giving birth, illness, sabbaticals and unpaid leave. The proportion of regional inspectors pointing to these reasons is significantly higher than that of school principals.

About a quarter of the regional inspectors consider two other reasons for the demand for teachers - teachers leaving the profession (26\%) and changes in educational policies $(24 \%)$, which include, for example, adding hours to certain school subjects. Only $12 \%$ of the school principals consider these to be major reasons. The 
introduction of new curricula is not considered by either group as a major reason for hiring new teachers.

This pattern of findings is similar in elementary and secondary schools and in the secular, religious and Arab sectors.

\subsection{Teacher Supply and Demand Throughout the Year in General and in Specific School Subjects}

Findings related to this question were obtained by analyzing the want ads and job-seekers ads posted on teachers' union internet sites. It was found that these advertisements mainly relate to Hebrew speaking schools; a finding which was corroborated by data obtained in the survey of principals, according to which principals in Arab schools do not use these internet sites for recruiting teachers. On these measures, there were no differences between elementary and secondary schools.

\subsubsection{Supply and Demand in General throughout the Year}

The following figures show the number of teachers needed or seeking teaching positions in elementary schools (Figure 1) and in secondary schools (Figure 2).

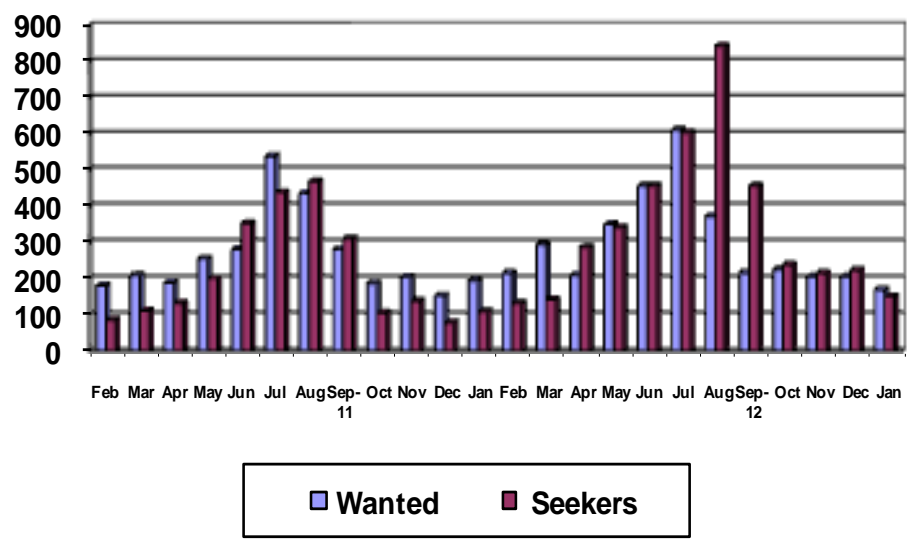

Figure 1. Number of teachers needed in schools and number of teachers seeking work in elementary schools per month

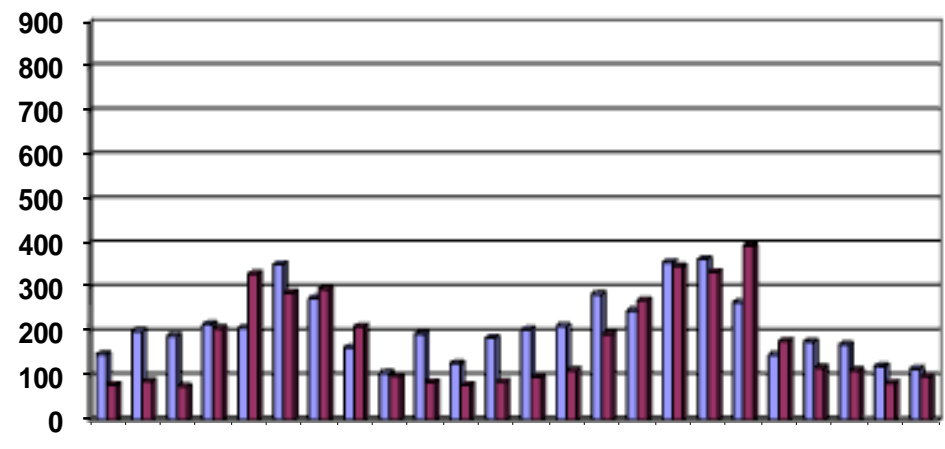

Feb Mar Apr May Jun Juk Aug Sep- Oct Nov Dec Jan Feb Mar Apr May Jun Jul Aug Sep- Oct Nov Dec Jan

\section{$\square$ Wanted $\square$ Seekers}

Figure 2. Number of teachers needed in schools and number of teachers seeking work in secondary schools per month

Figure 1 and Figure 2 indicate that on both school levels, there is a continual search for teachers throughout the year. The number of teachers needed per month on the elementary level ranges from 150 to 610 , while the number of job seekers each month ranges from 80 to 250 . The number of teachers needed per month on the secondary level ranges from 80 to 400 , while the number of job seekers each month ranges from 100 to 350. Peaks of supply and demand on both levels occur in the summer months (June-August).

Since a shortage is defined as a gap between supply and demand, we have chosen to graphically present these gaps, which were computed by subtracting the number of teachers needed from the number of job seekers. Figure 3 presents these gaps throughout the two years on the elementary and secondary levels.
The zero line represents a balanced state between supply and demand. Values below the zero line indicate a shortage of teachers while values above zero indicate a surplus of teachers.

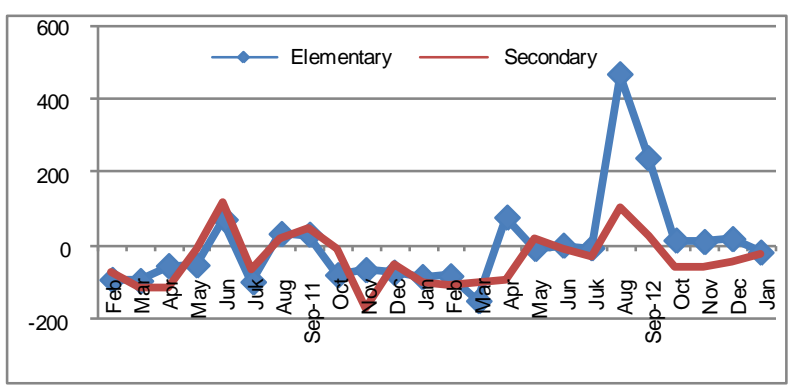

Figure 3. Gaps between teachers needed and job seekers per month 
As can be seen in Figure 3, in most months, demand exceeds supply on both school levels. In some of the summer months and especially toward the beginning of the school year, there is a balance between supply and demand. At times the supply is higher than demand, as can be seen in elementary schools at the beginning of the 2012 school year. This surplus results from more teachers seeking teaching positions not because of a decrease in the demand for teachers.

\subsubsection{Supply and Demand in Different School Subjects throughout the Year}

There are fourteen school subjects taught on the elementary level including general teaching, which refers to teachers who teach a number of school subjects and also serve as homeroom teachers. On the secondary level, there are seventeen school subjects. For each of these subjects, we calculated the gaps between supply and demand per month. Here too, values below zero indicate a shortage in teachers while values above zero indicate a surplus. The analysis revealed huge variability in the different school subjects with a shortage found in some school subjects, a surplus in a few, and balance in all the others.

On the elementary level, there are six subject areas where the demand for teachers exceeds the supply in most months. In descending order according to the two-year average gap, these are: general teaching (-55.83), English (-10.5), music (-6.21), sciences (-6.0) and to some extent in Hebrew language and literature (4.42) and mathematics (-4.25). These gaps are somewhat balanced during the summer months and toward the beginning of the school year. In two subject areas, the supply exceeds demand: special education (45.71) and Bible and Jewish studies (19.42). In the other six subjects, the average gap evens out: Computers (3.67), history (2.54), arts (1.08), geography (1.0), Arabic (-0.29) and physical education ($0.75)$.

On the secondary level, there are five school subjects with teacher shortages, three of them similar to the elementary level: Hebrew language (-16.17), English (5.50), sciences/biology (-13.96), mathematics (-7.50) and to a certain extent Arabic as a second language (-4.13). The magnitude of the gaps is more notable on the secondary level than on the elementary level. A subject area with a surplus of teachers, similar to the elementary level, is Bible and Jewish studies (14.42).

In the other eleven subjects, there is a balance between supply and demand: special education (3.29), civics (3.25), history (2.88), art (2.71), physical education (1.46), music (0.58), chemistry (-0.38), Hebrew literature (-0.88), computers and computer science $(-2.00)$, physics $(-2.67)$, and geography (-3.38). The leveling of the gaps occurs mostly during the summer months and on the eve of the new school year.

Below is a graphic display of the gaps in three chosen subjects on the elementary and secondary levels: English (Figure 4a), Bible and Jewish studies (Figure 4b), and special education (Figure 4c). While on both school levels, a shortage is evident in English and a surplus of teachers is evident in Bible and Jewish studies, a different pattern emerges in special education, with a surplus on one level and a shortage in the other. The raw data is presented in Table 2.

Table 2. Gaps between Supply and Demand in Three School Subjects on the Elementary and Secondary Levels

\begin{tabular}{|c|c|c|c|c|c|c|}
\hline & \multicolumn{2}{|c|}{ English } & \multicolumn{2}{|c|}{ Special Education } & \multicolumn{2}{|c|}{ Bible \& Jewish Studies } \\
\hline & Elementary & Secondary & Elementary & Secondary & Elementary & Secondary \\
\hline Range 'want' & $10-60$ & $10-50$ & $3-33$ & $5-22$ & $0-5$ & $5-25$ \\
\hline Range 'seek' & $10-50$ & $2-30$ & $23-226$ & $1-47$ & $2-70$ & $5-60$ \\
\hline Feb & -11 & -5 & 12 & -6 & 5 & 2 \\
\hline Mar & -21 & -18 & 30 & -4 & 5 & -2 \\
\hline Apr & -8 & -17 & 23 & 1 & 8 & 4 \\
\hline May & -12 & 3 & 23 & -2 & 18 & 26 \\
\hline Jun & 1 & -1 & 48 & 3 & 38 & 40 \\
\hline Jul & -22 & -35 & 70 & -9 & 36 & 33 \\
\hline Aug & -3 & -19 & 98 & 13 & 56 & 46 \\
\hline Sep 2011 & -9 & -1 & 40 & 12 & 15 & 18 \\
\hline Oct & -2 & -10 & 5 & 4 & 6 & 9 \\
\hline Nov & -13 & -29 & 9 & -12 & 9 & 14 \\
\hline Dec & -12 & -24 & 15 & 3 & 1 & 1 \\
\hline Jan & -9 & -21 & 4 & -4 & 1 & -12 \\
\hline Feb & -20 & -10 & 26 & 0 & 6 & 3 \\
\hline Mar & -28 & -18 & 20 & 0 & 2 & -2 \\
\hline Apr & -9 & -26 & 52 & 1 & 9 & 8 \\
\hline May & -16 & -7 & 78 & 14 & 23 & 19 \\
\hline Jun & -14 & -18 & 74 & 9 & 33 & 26 \\
\hline Jul & -25 & -28 & 106 & 9 & 39 & 34 \\
\hline Aug & 10 & -10 & 200 & 36 & 67 & 32 \\
\hline Sep 2012 & -4 & -18 & 66 & 22 & 34 & 10 \\
\hline Oct & -13 & -18 & 47 & 0 & 10 & 5 \\
\hline Nov & -11 & -23 & 2 & -1 & 24 & 8 \\
\hline Dec & 2 & -5 & 31 & -7 & 9 & \\
\hline Jan & -3 & -14 & 18 & -3 & 12 & 15 \\
\hline Mean Gap & -10.5 & -15.50 & 45.71 & 3.29 & 19.42 & 14.42 \\
\hline
\end{tabular}




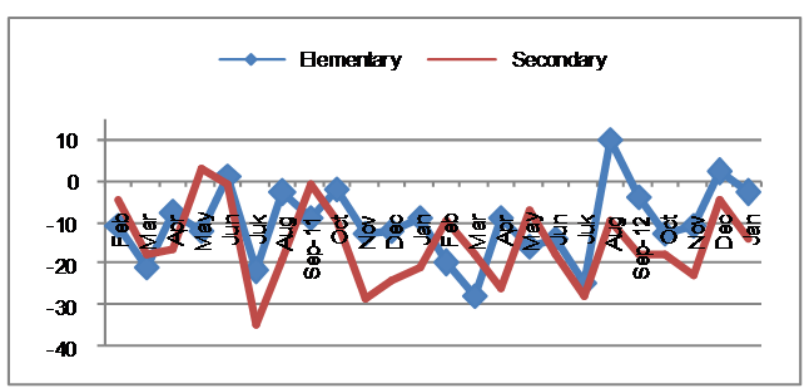

Figure 4a. Gaps between teachers needed and job seekers per month in English

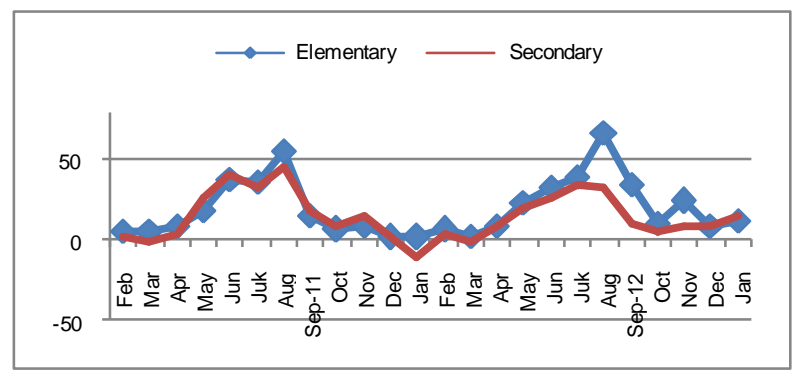

Figure 4b. Gaps between teachers needed and job seekers per month in Bible and Jewish studies

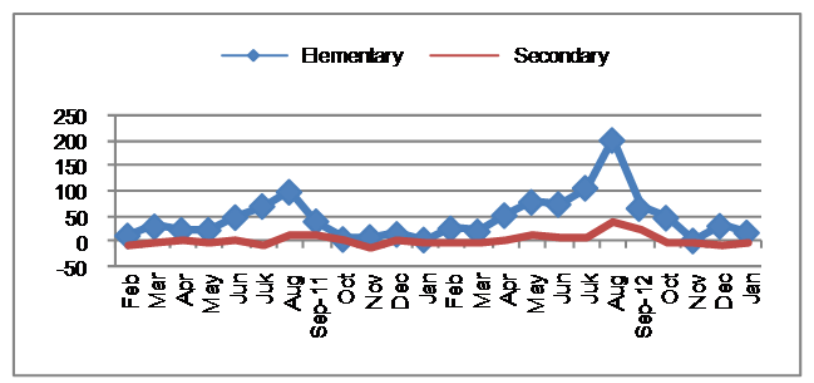

Figure 4c. Gaps between teachers needed and job seekers per month in special education

\subsection{Strategies Used by School Principals in order to Cope with the Teacher Shortage According to Principals and Regional Inspectors}

Ten possible strategies used by school principals for coping with the teacher shortage appeared in principals and inspectors' survey questionnaires. These were merged into five categories according to a factor analysis procedure using principal axis factoring with an orthogonal rotation. Table 3 presents these categories in descending order according to the percentage in which they are frequently and very frequently used by principals as reported by principals and inspectors.

The most common strategy used frequently by principals to cope with teaching shortages is increasing the teaching loads of existing teachers. $41 \%$ of the principals and $71.5 \%$ of the inspectors reported on the usage of this strategy frequently and very frequently. The following two categories used frequently and very frequently according to principals and inspectors are hiring under-qualified teachers (49\% and 25\% respectively) and employing substitute, temporary teachers for long periods of time (45\% and $24 \%)$.
Table 3. Percentage of principals who 'frequently' and 'very frequently' use different strategies to cope with the teacher shortage according to principals and inspectors

\begin{tabular}{|c|c|c|c|}
\hline & Principals & Inspectors & $\chi 2(p)$ \\
\hline $\begin{array}{c}\text { Increasing teaching loads of } \\
\text { existing teachers }\end{array}$ & $\% 41$ & $71 \%$ & $11.50 * *$ \\
\hline Hiring under-qualified teachers & $\% 25$ & $49 \%$ & $7.01 * *$ \\
\hline $\begin{array}{l}\text { Employing substitutes, temporary } \\
\text { teachers for long periods of time }\end{array}$ & $\% 24$ & $45 \%$ & $6.52 * *$ \\
\hline $\begin{array}{c}\begin{array}{c}\text { Structural reorganization in } \\
\text { school }\end{array} \\
\text {. }\end{array}$ & $\% 14$ & $21 \%$ & 1.42 \\
\hline Offering incentives and bonuses & $\% 2$ & $20 \%$ & $4.15^{*}$ \\
\hline
\end{tabular}

$* \mathrm{p}<.05 * * * \quad \mathrm{p}<.001$

Internal reorganization of the school (enlarging classes, shrinking the curricula, cancelling subjects) is a much less common strategy reportedly used frequently $(21 \%$ and $14 \%)$. Using tempting personal contracts and offering financial benefits to attract teachers is reported as used frequently only in a few cases according to the principals (2\%), and to a larger extent according to the inspectors $(20 \%)$.

\subsection{The Effect of Teacher Shortage on Teaching and Learning in Schools According to Principals}

Six categories were delineated from the responses of 40 principals to the open question which asked them to describe the effect of the teacher shortage on various aspects of learning and teaching in their schools. Table 4 presents these categories.

Table 4. Percentage of Principals Indicating the Following Six Categories as Having Effects on their School

\begin{tabular}{|c|c|c|c|}
\hline Effects of shortage & $\mathrm{N}$ & $\%$ & Details \\
\hline $\begin{array}{c}\text { Lower teaching } \\
\text { quality }\end{array}$ & 32 & $\% 80$ & $\begin{array}{c}\text { Teachers' lack of disciplinary } \\
\text { knowledge, disturbing the sequence } \\
\text { of learning }\end{array}$ \\
\hline $\begin{array}{c}\text { Lower } \\
\text { achievements }\end{array}$ & 24 & $\% 60$ & $\begin{array}{l}\text { Low attainment, decease in the } \\
\text { percentage of students passing the } \\
\text { national exams }\end{array}$ \\
\hline $\begin{array}{l}\text { Burden on } \\
\text { managerial aspects } \\
\text { in schools }\end{array}$ & 15 & $\% 38$ & $\begin{array}{c}\text { Administrative burden, high } \\
\text { turnover, causing inconvenience, } \\
\text { draining time and energy, effecting } \\
\text { school climate, causing chaos and } \\
\text { turmoil }\end{array}$ \\
\hline $\begin{array}{l}\text { Discipline } \\
\text { problems }\end{array}$ & 10 & $\% 25$ & $\begin{array}{l}\text { Lack of communication between } \\
\text { teachers and students, severe } \\
\text { discipline problems, difficulties in } \\
\text { classroom management }\end{array}$ \\
\hline $\begin{array}{l}\text { Failure to meet } \\
\text { standards }\end{array}$ & 6 & $\% 15$ & $\begin{array}{l}\text { Failure to meet the standards and } \\
\text { requirements of the Ministry of } \\
\text { Education, lagging behind } \\
\text { timetables, not meeting expectations }\end{array}$ \\
\hline $\begin{array}{c}\text { Parental } \\
\text { dissatisfaction }\end{array}$ & 5 & $13 \%$ & $\begin{array}{l}\text { Parents complain, harming } \\
\text { relationships with parents }\end{array}$ \\
\hline
\end{tabular}

As can be seen in Table 4, the most significant effects of the teacher shortage according to principals relate to the quality of teaching (80\%), student outcomes $(60 \%)$, and ongoing effective management of the school (38\%).

\section{Discussion and Conclusions}

The aim of this study was to examine the controversial matter of teacher supply and demand in Israel using data obtained on the school and district levels. This state of ambiguity is not unique to the Israeli setting, as noted by other researchers: 'Despite the long-standing prominence of this issue as a national policy concern, empirical 
research on the adequacy of the quantity of the supply of teachers has been surprisingly limited - in data methods and measured' [[5], p. 565].

While most studies conducted in this area are based on data obtained from macro level sources, the purpose of this study was to focus on the micro level, i.e., activities taking place within the schools in order to cope with the teacher shortage. Support for this course of action was drawn from organizational theory, which claims that there is a need to focus on the organizational level, and from previous research that highlighted the importance of examining teacher shortage and coping with it from the perspective of the schools themselves [22,23]. Another attempt at analysis implemented in this study was to collect data from job advertisements in order to gain some quantitative information regarding the magnitude of the teacher shortage. To the best of our knowledge, this methodology has never been used before for such purposes. The use of these two methodologies -surveys and analysis of internet ads - also caused the limitations of this study as elaborated below.

\subsection{Reasons for Teacher Demand}

Two main reasons for the need for teachers were identified by school principals and inspectors. The first is demographic growth in the school population. This aspect is considered a major one, if not the most important factor that affects the need for teachers [1,24]. Although it is seemingly a fairly easy factor to consider when predicting shortage, it itself is effected by many other sensitive factors and every slight change in them might bias the predictions [24]. These include changes in student enrollment, immigration to the country, internal emigration, teachers moving within the system from one school level to another, from one supervisory segment to another, from one school subject area to another, and changes related to student characteristics such as special education students, etc.

A second reason mentioned by many of the principals and even more so by the inspectors as having an immediate effect on the need for teaches is temporary leaves of teachers. Reasons for this short-term leave are varied and include maternity leave, sick leave, and sabbatical leave. All these require hiring teachers for a sometimes unknown period of time that can occur during the school year and might be prolonged beyond what was originally expected. The difference between the lower estimations of principals in this respect versus those of inspectors, which were much higher, can be attributed to the fact that inspectors have a broader outlook on the situation based on information gathered from the many schools in their districts.

The picture which emerges from the internet ads of a constant shortage during the school year strengthens the 'temporary leave' as a significant factor affecting the need for teachers. It is evident that recruiting teachers is a problem that preoccupies school principals throughout the year and not only toward the beginning of the school year. We found support for this finding in a report by the State Comptroller [25] that claimed that even when more accurate predictions can be made regarding temporary leave, the Ministry of Education does not handle this properly. For example, six weeks after all requests for a sabbatical were transmitted, the Ministry had processed only $85 \%$ of these requests.

\subsection{The Dynamics of Supply and Demand of Teachers - In General and Per School Subjects}

An answer to this question was obtained by analyzing job advertisements which included both 'wanted' ads advertised by schools offering teaching positions, and 'job search' ads of individuals seeking teaching positions. The picture that emerged shows an ongoing search for teachers throughout the school year with usually fewer job seekers than needed to fill the empty positions in most months. Thus, during the entire year, principals face difficulties in filling empty teaching positions. Toward the summer months, the supply and demand are more balanced and there is even a certain surplus in teachers seeking teaching positions. This allows school principals to be more selective in choosing appropriate teachers for the jobs. This pattern was found to be similar in the two years that were examined. Although there was a greater supply of teachers in elementary schools in 2013 versus 2012, it is still hard to detect trends from this specific finding. This finding may point to activities initiated by the Ministry of Education aimed at enlarging the supply of teachers, such as the opening of alternative routes of certification.

The recurring finding - that there is a surplus of teachers on the eve of the new school year - raises the question of whether these are the qualified teachers that principals are looking for. There is no definite answer to this question based on the internet ads, since some of the job seekers describe their qualifications in great detail while others don't. Yet, in numerous ads, applicants clearly state that they do not hold a teaching certificate nor have any prior experience in teaching. It can thus be concluded that the profile of job seekers is varied and also includes candidates with no certification or proper qualifications. Entry of such candidates is an immediate threat to the quality of the Israeli teaching force. It should also be pointed out that the finding that there is a massive demand for teachers in October-November, only a short while after the school year has begun, is particularly worrisome. This could be the result of new teachers abandoning their classes due to maladjustment and difficulties in adaptation to the profession. This particular finding should be examined in future studies.

When examining the gap between supply and demand in the different school subjects, it is clear that in some subject areas, there is a severe shortage, while in others, a surplus is found. The school subjects in which shortage is evident on all school levels are English, math and sciences. This finding is in line with the data provided by the Ministry of Education [26]. During the years 2009-2012, as a result of this acknowledged shortage, the Ministry of Education initiated several ad-hoc alternative programs to train university graduates in these three fields [27]. According to the State Comptroller [25], in 2010 only a third of the math teachers on the secular Jewish secondary level had the necessary qualifications to teach. A chronic shortage in math and science teachers is also evident in other western countries, including the US, and forces schools to lower recruiting standards for teachers in these subject areas [28]. As to English, it is difficult to compare 
the demand for teachers in English-speaking countries versus countries where English is taught as a foreign language such as Israel [29].

On the secondary level, there is also variance within the different scientific disciplines, with a shortage found in science technology and biology but not in physics and chemistry. According to the CBS [30], more students are studying biology than physics or chemistry; data which could partially explain the shortage in biology. In other words, the shortage is due to the fact that more students choose to study biology. These findings do not correspond to the situation in the US where a severe shortage appears in physics compared to chemistry and biology [31].

Despite the claim by the Ministry of Education that a teacher shortage exists only in English, math and sciences, analysis of internet ads reveals a severe shortage on the elementary school level in general classroom teachers and on the secondary level in Hebrew language teachers. General classroom teachers on the elementary level usually teach a varied array of school subjects such as Hebrew language, Bible, math and science. Those in favor of this model raise the concern that if taught by many teachers, youngsters at this age would not be able to develop a close relationship with their teachers [32]. However, changes in teacher preparation models in Israel during the $90 \mathrm{~s}$ suggested elimination of the general classroom teacher role. This new policy was based on the assumption that general teachers are less qualified to transmit knowledge in the various disciplines [33]. As a result, since 2009, every teacher is required to hold an academic degree in a specific discipline or at least a disciplinary specialization that will ensure the quality of his or her teaching [33]. However, in many schools there are still numerous teachers who were trained according to the previous model and the findings of this study suggest that school principals themselves are reluctant to adopt the new model and prefer the previous one. A research team that looked into this matter compared the situation in Israel to that existing in other countries supported the model of integrated teaching by homeroom teachers, especially in the lower elementary grades [32]. In addition, a report by the State Comptroller (2013) identified a nonsystematic approach by the Ministry of Education toward the school subjects that can be taught by a general teacher.

On the secondary school level, the main shortage exists in mother tongue Hebrew language teachers. This finding is not surprising light of the decrease of $50 \%$ in the number of university students graduating in this area in 2009-2010 as compared to 2004-05. In addition, the number of students studying Hebrew language at the teachers colleges (data from 2009-2010) is the lowest amongst all subjects [30]. To exemplify the magnitude of the difference, the number of students studying to become literature teachers was three times greater than those studying Hebrew language [30]. Taking into consideration that Hebrew language is an obligatory school subject taken by more than $90 \%$ of the secondary students [34], it is no wonder that this is the subject where the shortage is most acute.

Other school subjects in which the need for teachers is evident, although to a lesser extent, are music on the elementary school level and Arabic language on the secondary level. The shortage in music teachers may be explained by the number of students studying music at academic colleges of education which was the lowest in 2009-2010, compared to all other arts studies. As for Arabic language, given the social and political climate in Israel, it is no wonder that Arabic teaching is not a prioritized teaching career [35].

The analysis of internet ads also revealed some school subjects where supply exceeds demand. This situation particularly characterizes special education on the elementary school level and Bible and Jewish studies on both school levels. Regarding special education, an explanation for this situation relates to the large number of applicants studying special education at teacher colleges of education [20]. This is a completely different situation from that found in the US, where there is a severe shortage of teachers in this area [36], and could be the result of viewing the special education specialization as a springboard toward studying various types of therapy [37]. The surplus in Bible and Jewish studies teachers can be attributed to the fact that this subject is ranked third in the number of students studying it at the teacher colleges [20].

In general, our findings indicate a higher demand for teachers on the elementary level than on the secondary level. Apart from the fact that there are more elementary schools than secondary schools in Israel, there could be other reasons, such as the composition of the workforce on the elementary level which includes more women and younger teachers, two factors that were found to increase the tendency for temporary leaves and a more significant drop-out of teachers [38].

\subsection{Strategies Carried Out by School Principals in Response to the Need for Teachers and their Effect on the Quality of Teaching}

Strategies carried out by school principals to cope with the need for teachers affect both quantitative and qualitative aspects of the teacher shortage. Our findings show that the most common strategies implemented are increasing the teaching loads of existing teachers, employing under-qualified teachers or, alternately, employing temporary teachers for long periods of time. These three strategies have a negative impact on the quality of teaching and learning in schools. Increasing teaching loads causes teacher burnout, employing underqualified teachers directly effects teaching as these teachers do not hold a teaching certificate at all or hold a teaching certificate for subjects others than the ones they teach. Hiring teachers to teach other school subjects or other school levels than the ones they were certified for (out-of-field) is common in other counties and is constantly increasing [4,39]. These data mask the real shortage of teachers [40], affect the teachers themselves [41], lower the pupils' chance to receive quality education [42] and lessen the ability to operate the curriculum as mandated by state decisions [40]. The third strategy of employing temporary teachers for long periods of time causes high turnover rates which lead to an extra burden on schools. These temporary personnel are usually less committed to the system and are also not under inspectorate scrutiny as regular teachers are.

All these strategies represent a compromise made by principals who themselves describe the negative effects of 
employing under-qualified teachers, among them lowering the quality of teaching, lessening student achievement, interfering with the management of schools, causing discipline problems, not meeting school goals and causing parents' complaints. These effects were also detected in the literature [1]. It should be noted that research on affective schools has found a correlation between school affectivity and the quality of the teachers teaching in it and pointed to the fact that school principals 'can control the quality of the teaching force at their school by hiring highquality teachers; by strategically retaining good teachers... and by assigning them to classes for which they are best suited' [[43], p. 5].

It can thus be concluded that even though there isn't necessarily a quantitative shortage at the beginning of the school year according to the ads, many of the teachers who occupy these teaching positions are those that school principals had to accept as a compromise, as Ingersol and Perda state, 'in reality... schools often simply cannot, and do not, leave teaching positions unstaffed, regardless of the quantity and quality of supply' [[5], p 565]. It is likely that school principals can choose among candidates only in the case of school subjects where there appears to be a surplus of teachers looking for jobs. These findings redirect the problem of the quantitative teacher shortage toward the problem of a hidden shortage and the quality of the teaching force.

Findings of this study show that the supply and demand issue which is vital to planning and forecasting teacher preparation remains to a large extent unsolved. The job market operates under the rules of supply and demand and when supply is low, school principals recruit candidates with inadequate qualifications. Thus, quantitative predictions do not reflect the qualitative shortage. In order to overcome this vulnerable area, there is a need for a detailed database that provides information regarding the extent to which teaching positions are filled with adequate candidates. This database does not yet exist.

\subsection{Limitations of the Study}

A number of limitations should be pointed out. First, the fairly low response rate of school principals, which does not allow us to examine differences within subsectors including geographic regions. Although the regional inspectors' survey validated the principals' responses to some extent, we should still be cautious about the data obtained. A second limitation relates to the utilization of internet ads as a source of information, as we do not know for sure the extent of the use of this platform by school principals and job-seekers. In addition, we should keep in mind that while schools advertise only once on the internet, job-seekers may advertise more than once in varied formats, a situation which leads to an overestimation of the number of candidates.

\section{Acknowledgements}

This work was supported by the Israeli Ministry of Education and the Mofet Institute.

\section{References}

[1] Santiago, Paulo. 2002. Teacher Demand and Supply: Improving Teaching Quality and Addressing Teacher Shortages. OECD Publishing.

[2] Schleicher, Andreas 2012. Preparing Teachers and Developing School Leaders for the 21st Century: Lessons from around the World: OECD Publishing.

[3] Eurydice. 2002. The Teaching Profession in Europe: Profile, Trends, and Concerns. Teacher Supply and Demand at General Lower Secondary Level. Key Topics in Education in Europe. Brussels: European Commission / Eurydice.

[4] Ingersoll, Richard M. 2003a. Out-of-Field Teaching and the Limits of Teacher Policy. Report of the Center for the Study of Teaching and Policy and The Consortium for Policy Research in Education 32, University of Pennsylvania.

[5] Ingersoll, Richard M, and David Perda. 2010. "Is the Supply of Mathematics and Science Teachers Sufficient?" American Educational Research Journal 47 (3): 563-94.

[6] Ehrenberg, Ronald G., and Robert S. Smith. 1997. Modern Labor Economics. 6th ed. Reading, MA: Addison-Wesley.

[7] Guarino, Cassandra M, Lucrecia Santibanez, and Glenn A Daley. 2006. "Teacher Recruitment and Retention: A Review of the Recent Empirical Literature.” Review of Educational Research 76 (2): $173-208$.

[8] King Rice, Jennifer, Christopher Roellke, Dina Sparks, and Tammy Kolbe. 2009. "Piecing Together the Teacher Policy Landscape: A Policy Problem Typology." The Teachers College Record 111 (2): 511-46.

[9] Cannata, Marisa. 2010. "Understanding the Teacher Job Search Process: Espoused Preferences and Preferences in Use.” Teachers College Record 112 (12): 2889-934.

[10] Ingersoll, Richard M. 2003b. "The Teacher Shortage: Myth or Reality?" Educational Horizons 81: 146-52.

[11] Stolzenberg, Ross M. 1978. "Bringing the Boss Back In: Employer Size, Employee Schooling, and Socioeconomic Achievement."American Sociological Review 43 (6): 813-28.

[12] Ingersoll, Richard M. 1999. "The Problem of Underqualified Teachers in American Secondary Schools." Educational Researcher 28 (2): 26-37.

[13] Liu, Edward, Joseph G Rosenstein, Aubrie E Swan, and Deena Khalil. 2008. "When Districts Encounter Teacher Shortages: The Challenges of Recruiting and Retaining Mathematics Teachers in Urban Districts." Leadership and Policy in Schools 7 (3): 296-323.

[14] Yogev, Abraham. 2006. "The Dovrat Report and the Teachers: For Whom Will the Bells Toll?" In Toward an Educational Revolution, edited by Dan Inbar, 177-84. Jerusalem \& Tel Aviv: The Van Leer Jerusalem Institute and Hakibbutz Hameuchad (Hebrew).

[15] CBS (Central Bureau of Statistics) 2007. Forecast for the Teaching Force in the Educational System, 2006-2012. Jerusalem (Hebrew).

[16] CBS (Central Bureau of Statistics) 2010. Statistical Abstract of Israel 2010 No. 61. Jerusalem (Hebrew).

[17] CBS (Central Bureau of Statistics) 2006b. The Teaching Force in the Educational System, 1991-2006. Jerusalem (Hebrew).

[18] Kfir, Drora, and Tamar Ariav. 2008. "Introduction." In The Crisis in Teacher Education: Reasons, Problems and Possible Solutions, edited by Drora Kfir and Tamar Ariav, 9-15. Jerusalem \& Tel Aviv: The Van Leer Jerusalem Institute and Hakibbutz Hameuchad (Hebrew).

[19] CBS (Central Bureau of Statistics) 2006a. Entrance of Teacher Training College Graduates into the Teaching Force, 1990-2000. Jerusalem (Hebrew).

[20] CBS (Central Bureau of Statistics) 2011. Statistical Abstract of Israel 2011 No. 62. Jerusalem (Hebrew)

[21] CBS (Central Bureau of Statistics) 2009. Media Release: Teacher Shortage Projections. Jerusalem (Hebrew).

[22] Jacob, Brian A. 2007. "The Challenges of Staffing Urban Schools with Effective Teachers.” The Future of Children 17 (1): 129-53.

[23] Jacob, Brian A, and Lars Lefgren. 2008. "Can Principals Identify Effective Teachers? Evidence on Subjective Performance Evaluation in Education." Journal of Labor Economics 26 (1): 101-36.

[24] Blass, Nachum. 2010. "Is There a Shortage of Teachers? Policy Paper 14." Jerusalem: Taub Center for Social Policy Studies in Israel (Hebrew).

[25] State Comptroller of Israel. 2013. Aspects of Manpower Management in the Education System. Annual Report 63c (Fiscal Year 2012). Jerusalem (Hebrew). 
[26] Worgan, Yuval., and Itay. Fidelman. 2008. Teacher Shortage in the Educational System. Jerusalem: Government Research Center (Hebrew).

[27] Donitsa-Schmidt, S. \& Weinberger, J. (in press). Do alternative teacher-education programs manage to attract different candidates and students? Journal of Teacher Development.

[28] Ingersoll, Richard M, and Henry May. 2012. "The Magnitude, Destinations, and Determinants of Mathematics and Science Teacher Turnover." Educational Evaluation and Policy Analysis 34 (4): 435-64.

[29] Mitchell, Rosamond, Florence Myles, and Emma Marsden. 2013. Second Language Learning Theories. London: Routledge.

[30] CBS (Central Bureau of Statistics) 2012b. Statistical Abstract of Israel 2012 No. 63. Jerusalem (Hebrew).

[31] U.S. Department of Education. 2009. Teacher Shortage Areas Nationwide Listing 1990-91 to 2009-10. Washington, DC: Department of Education.

[32] Ben-Peretz, Miriam, Estie Yankelevitch, Madene Shachar, and Meyran Boniel-Nissim. 2006. An Examination of the Roles of Teachers in Israeli Elementary Schools Compared to Other Countries. Jerusalem: Ministry of Education (Hebrew).

[33] Weisblay, Etti. 2012. Correspondence between Teacher Discipline and the School Subjects Taught by Teachers: Situation Report. Jerusalem: The Knesset Research \& Information Center (Hebrew).

[34] CBS (Central Bureau of Statistics) 2012a. Number of Teaching Hours in Secondary Schools. Jerusalem (Hebrew).

[35] Donitsa-Schmidt, S., Inbar, O. and Shohamy, E. (2004). The effects of teaching spoken Arabic on students' attitudes and motivation in Israel. Modern Language Journal, 88 (2), 218-229.
[36] Boe, Erling E. 2006. "Long-Term Trends in the National Demand, Supply, and Shortage of Special Education Teachers." The Journal of Special Education 40 (3): 138-50.

[37] Lavian, Rivka Hillel. 2013. "You and I Will Change the World" Student Teachers' Motives for Choosing Special Education." World Journal of Education 3 (4).

[38] Arbiv-Elyashiv, Rinat, and Varda Zimmerman. 2013. "Why Do Teachers Leave Teaching?" Paper presented at the Sixth International Conference on Teacher Education, Changing Reality through Education, at the David Yellin Academic College of Education, Jerusalem.

[39] Jerald, Craig D, and Richard M Ingersoll. 2002. All Talk, No Action: Putting an End to out-of-Field Teaching. Washington, DC: The Education Trust.

[40] McConney, Andrew, and Anne Price. 2009. "Teaching out-ofField in Western Australia." Australian Journal of Teacher Education 34 (6): 6.

[41] Pillay, Hitendra K, Richard Goddard, and Lynn A Wilss. 2005 "Well-Being, Burnout and Competence: Implications for Teachers." Australian Journal of Teacher Education 30 (2): 22-33.

[42] Dee, Thomas S, and Sarah R Cohodes. 2008. "Out-of-Field Teachers and Student Achievement Evidence from Matched-Pairs Comparisons." Public Finance Review 36 (1): 7-32.

[43] Loeb, Susanna, Demetra Kalogrides, and Tara Béteille. 2012. Effective Schools: Teacher Hiring, Assignment, Development, and Retention. Working Paper No. 17177. Cambridge, MA: National Bureau of Economic Research. 